\title{
Capital Market Reactions on The Event Of The American Presidential Election In 2016 (Case Study Of Listed Companies In Indonesia And American Stock Exchange)
}

\author{
Aris Andriyani \\ Department of Management \\ STIE Malangkucecwara \\ Malang, Indonesia \\ arisandriyani94@gmail.com
}

\author{
Dwi Nita Aryani \\ Department of Management \\ STIE Malangkucecwara \\ Malang, Indonesia \\ dwinita@stie-mce.ac.id
}

\begin{abstract}
The aim of this study is to analyze the reaction of the Indonesian and American capital markets to the events of the 2016 America presidential election. The method used in this research is event study to analyze market reaction and test $t$-test (paired samples t-test) to analyze difference of high low spread (high and low price difference), stock price average, stock returns and trading activity volumes (TVA) before and after election events. For Indonesia, the sample in this research is $\mathbf{3 0}$ companies of LQ45 while for America is 30 companies of Dow Jones Industrial Average (DJIA). T-test were be used to test market reactions before and after the events of the presidential election. The results show that in Indonesia, statistically before and after the US presidential election, the average spreads, stock prices and TVA are different and decrease. While in America, the spread value, the average stock price and TVA are different and increased. The US presidential election in 2016 contains meaningful information for investors, where president election events can be one of the factors that affect the capital market.
\end{abstract}

Keyword-stock; LQ45; DJIA; presidential election of America; market reaction

\section{INTRODUCTION}

The United State (US) is a developed country which the politics or economics changing may affect other countries on economics, technology, regulation and politics. This is proven by US Dollar, as a benchmark currency that be used by almost countries in the world. On November 8th 2016, US held a 45th president election and the candidates were Hillary Clinton and Donald Trump. The result of the election might affect not only
US itself but also other countries condition, due to US is a superpower country.

Wellian Wiranto an economist of OCBC Singapore [1] mentioned that approaching presidential election, global market would make an anticipation movement regarding to result of this election. If Donald Trump wins to replace Barack Obama, it would influence trading sector in America and other partner countries. In Trump's campaign, he said that he will increase duties of good particularly import from China. It is plausible that his policy might influence other countries which have partnership with China.

Donald Trump's economic protection policy was expected to exacerbate the global economy, especially after China's economic slowdown. Singapore's Ambassador to Indonesia Anil Kumar Nayar, stated that many countries were worried about the policies that Donald Trump will take such as anti-immigration and import duties on imported goods. However, Asia was believed to be unaffected by Donald Trump's policy discourse, given that the Asian region accounted for $2 / 3$ of the global economy last year so it can be said that Asia has a strong economic foundation. In addition, Asia was also believed to be the driving force of the global economy in Donald Trump era, especially Southeast Asia which has various resources that can be developed. Asia is also still a promising market for the world, besides with the existence of MEA Asia can maintain economic integrity including Indonesia [2].

The capital markets have a role to the state economy and in the implementation of many things that affect the development of capital markets. The capital market is very sensitive to the problems of the country; therefore a mature strategy is needed in the management and planning. According to [3], there are several factors that 
influence the success of the capital market, namely securities supply, and demand for securities, political conditions, economy, legal and regulatory issues and the role of capital market support institutions.

A theory developed by Yale Hirsch states that the US stock market weakened in the year of the new presidential election of America. According to this theory, after the first year the stock market will improve until the cycle begins again with the next presidential election. However, after the mid-1900s, this theory was refuted. In 1937, when Franklin D. Roosevelt won the election, the market declined 27.3\%. Era Truman and Eisen also declined in the stock market. However, during the George Bush's election, the stock market showed a $25.2 \%$ increase and as Bill Clinton's market performance rose from $19.9 \%$ to $35.9 \%$ [4].

The above conditions indicated that the presidential election of America could have a significant impact on the economy of other countries. In addition, the economy in general and the capital market in particular is also taken into account as to its role in the state economy, so if there was economic turmoil then the possibility of capital markets would also be affected. Therefore, it is exciting to conduct a deeper examination is required in the term of the impact of the events of the American elections, especially on market reaction of spread of the highest and lowest share price, shares price, stock return, trading volume activities. Based on the description above, the aim of this research is to analyse market reaction of Indonesia Stock Exchange and the US Stock Exchange before and after the events of the 2016 US presidential elections by testing the differences between the average high and low spread, stock price averages, average of stock returns, average trading volume of stock activity.

\section{LITERATURE REVIEW}

The phases of market reaction of events are: 1) Accumulation phase. Investors, investment managers and traders start making purchases or called by accumulated periods. Because the price is still very attractive. The market condition in general is still declining 2) Mark up Phase, the stock price has stabilized and started to rise. 3) Distribution Phase, the stock sellers begin to make sales of shares that have been owned. In this part of the cycle, bullish sentiment is approaching the end, market sentiment has become neutral. Stock prices are flat. When this stage is over, there is a reversal direction. This stage of distribution is very emotional and fearful. 4) Mark Down Phase. The cost or investment has fallen below its purchase price. This stage is a buy signal for other market players, as a sign that stock prices reach bottom or Oversold Condition.

\section{A. Random Walk Theory}

According to [5], a researcher named Maurice Kendall in 1953, states that stock prices are unpredictable and random walk. Market price moves randomly interpreted that rising and falling stock prices depend on news information. New information is information that will be received and not yet known when received, therefore new information and stock prices are called unpredictable. The new information has not been known for certain whether good news (bad news) or bad news (bad news).

\section{B. Market efficiency}

The definition of market efficiency according to [6] is when all information needed by investors are available in the market and it can be accessed by investors, it reflects that market is efficient. Meanwhile, [7] asserted that the concept of market efficiency is more emphasized on the aspect of the information, which means that an efficient market is a market where the price of traded securities reflects all existing information

\section{RESEARCH METHODS}

\section{A. Types of Research}

This type of research includes event studies with the type of data used is quantitative data. The study of events is a study that studies an event against the stock price in the market at the time the event occurred and sometime after it happened. This study looks at whether the events that occur make stock prices increase or decrease [5]. The study was seen from 18 October-7 November before the presidential election and between 9-29 November 2016 after the 2016 US presidential election.

\section{B. Population and Sample}

The populations in this study are all companies listed on the stock exchanges of the United States which is about 7000 companies, and the Indonesian stock exchange which has 540 companies. The sample used for Indonesia is 30 listed companies of the LQ45 index, they are chosen by sampling based on the market value of capitalization. Meanwhile for the United States, the samples are 30 listed companies in Dow Jones Industrial Average (DJIA) index. 


\section{Observation Period}

In the event study, the observation period is divided into two: the observation period (event period) and the estimated period (estimation period). The period of the incident is the period surrounding the occurrence of election events, while the estimation period is the period before the election event occurred. In this study the observation period used is 30 days ie 15 days before the event of 2016 presidential election of America ( $t-15)$ and 15 days after the election $(t+15)$.

\section{Types and Data Sources}

The data used in this study are secondary data, namely shares of companies listed Indonesia Stock Exchange and the American Stock Exchange, consisting of: first, list of daily stock price of the company during the study period for each sample is obtained from the website of Indonesia Stock Exchange[8], and for American stock exchanges taken from [9], [10] and [11]. Second, the number of daily shares traded and the number of shares outstanding for each sample of the company during the period of the observation period. This data is obtained by accessing at [8]. Third, the highest and lowest prices for each sample of the company during the observation period are obtained from the Indonesian stock exchange website [8] and for the American stock exchange taken from [9]. Finally, Return of shares results are obtained from investment by calculating the stock price of the current period with the previous period.

\section{E. Variables and measurement}

Stock price is the average closing price of daily stock trading during the study period. Return of shares is an expected rate of return on the investments made in stocks or multiple stock groups through a portfolio.

$$
\text { Return }=\frac{F t-P t-1}{F t-1}
$$

Calculation of Trading Volume Activity is done by comparing the number of shares of the company traded in a certain period with the total number of shares outstanding from the company at the same time.

TVA $=\frac{\Sigma \text { Stock traded in t period }}{\Sigma \text { Shares outsanding in } t \text { period }}$

Spread is a percentage of the difference between the highest price (high price) with the lowest price (low price). The highest and lowest prices illustrate one's courage in selling or buying a stock. The high stock price is the highest price in the stock exchange at that time of day. As for the low price of the stock is the low price at that time of day. The highest and lowest prices may change over time, this can be influenced by internal and external conditions of the company.

\section{RESULT AND DISCUSSION}

\section{A. Hypothesis Testing (Indonesia Stock Exchange LQ45)}

The hypothesis in this study is the alleged "There are differences in high-low spread (H1), average stock price $(\mathrm{H} 2)$, stock return $(\mathrm{H} 3)$ and trading volume activity $(\mathrm{H} 4)$ before and after the election general president of the United States in 2016 in Indonesia (LQ45). The results of data processing before and after the events of the US presidential election in 2016 are showed at Table 1 and 2.

\section{TABLE 1. STATISTICAL RESULT BEFORE AND AFTER THE} EVENT ( LQ 45)

\begin{tabular}{|l|r|r|r|r|}
\hline \multicolumn{1}{|c|}{ Information } & \multicolumn{1}{c|}{$\mathbf{N}$} & \multicolumn{1}{c|}{$\begin{array}{c}\text { Min } \\
\text { value }\end{array}$} & $\begin{array}{c}\text { Max } \\
\text { Value }\end{array}$ & \multicolumn{1}{c|}{ Mean } \\
\hline Spread before election & 450 & 15 & 7500 & 222.76 \\
\hline Spread after election & 450 & 5 & 2700 & 300.93 \\
\hline $\begin{array}{l}\text { Stock price average } \\
\text { before election }\end{array}$ & 450 & 700 & 68125 & 10201.73 \\
\hline $\begin{array}{l}\text { Stock price average } \\
\text { after election }\end{array}$ & 450 & 665 & 67575 & 9594.07 \\
\hline Return before election & 450 & -0.08 & 0.06 & -0.00 \\
\hline Return after election & 450 & -0.11 & 0.11 & -0.05 \\
\hline TVA before election & 450 & 0.00 & 0.01 & 0.00 \\
\hline TVA after election & 450 & 0.00 & 0.01 & 0.00 \\
\hline
\end{tabular}

TABLE 2. CORRELATION AND PAIR T TEST (LQ45)

\begin{tabular}{|c|c|c|c|c|c|c|}
\hline $\begin{array}{c}\text { Information } \\
\text { (before and } \\
\text { after) } \\
\end{array}$ & $\mathbf{N}$ & Correlation & Sig. & Mean & $\mathbf{T}$ & $\begin{array}{c}\text { Sig. } \\
(2- \\
\text { tailed) } \\
\end{array}$ \\
\hline Spread & 450 & 0.46 & 0.00 & -78.18 & 3.63 & 0.00 \\
\hline $\begin{array}{l}\text { Stock price } \\
\text { average }\end{array}$ & 450 & 0.99 & 0.00 & 607.66 & 5.90 & 0.00 \\
\hline $\begin{array}{l}\text { Stock } \\
\text { Return }\end{array}$ & 450 & -0.02 & 0.72 & 0.003 & 1.78 & 0.08 \\
\hline TVA & 450 & 0.39 & 0.00 & -0.005 & $\overline{6.82}$ & 0.00 \\
\hline
\end{tabular}

The table above showed that the average spread, the average stock price and TVA before and after experience are different (Table 2), while the stock return value has no 
different. The minimum and maximum value are tend to decrease (table 1), This is evidenced by the value of sig $0.000<\alpha$ value $(0.05)$, so it is concluded that $\mathrm{H} 1, \mathrm{H} 2$, and $\mathrm{H} 4$ are significant different before and after the event of the 2016 US presidential election in Indonesia stock market (LQ45). According to [12], there are two factors that influence stock prices, namely internal factors such as announcements about marketing, funding production and others, while external such as government announcements, interest rates, inflation, political turmoil, issues from within and abroad. In his campaign Donald Trump expressed controversial policies such as antiimmigrants, forbidding Muslims to enter America, raising import taxes from China, this can directly or indirectly this will affect Indonesia [2].

\section{B. Hypothesis Testing (American Stock Exchange DJIA)}

TABLE 3. STATISTICAL RESULT BEFORE AND AFTER EVENT (DJIA)

\begin{tabular}{|l|c|c|c|c|}
\hline \multicolumn{1}{|c|}{ Information } & $\mathbf{N}$ & $\begin{array}{c}\text { Minimum } \\
\text { Value }\end{array}$ & $\begin{array}{c}\text { Maximal } \\
\text { Value }\end{array}$ & Mean \\
\hline $\begin{array}{l}\text { Spread before } \\
\text { election }\end{array}$ & 450 & 0.18 & 9.47 & 1.19 \\
\hline Spread after election & 450 & 0.19 & 10.67 & 1.50 \\
\hline $\begin{array}{l}\text { Stock price average } \\
\text { before election }\end{array}$ & 450 & 28.36 & 178.70 & 88.15 \\
\hline $\begin{array}{l}\text { Stock price average } \\
\text { after election }\end{array}$ & 450 & 29.52 & 215.52 & 92.10 \\
\hline $\begin{array}{l}\text { Return before } \\
\text { election }\end{array}$ & 450 & -0.15 & 0.86 & 0.01 \\
\hline Return after election & 450 & -0.05 & 0.08 & 0.00 \\
\hline TVA before election & 450 & 0.00 & 0.03 & 0.00 \\
\hline TVA after election & 450 & 0.00 & 0.03 & 0.01 \\
\hline
\end{tabular}

TABLE 4. CORRELATION AND PAIR T TEST (DJIA)

\begin{tabular}{|l|c|c|c|c|c|c|}
\hline $\begin{array}{l}\text { Informati } \\
\text { on (before } \\
\text { and after) }\end{array}$ & $\mathbf{N}$ & $\begin{array}{c}\text { Correlati } \\
\text { on }\end{array}$ & Sig. & Mean & $\mathbf{T}$ & $\begin{array}{c}\text { Sig. } \\
\text { (2- } \\
\text { tailed } \\
\text { ) }\end{array}$ \\
\hline Spread & 450 & 0.43 & 0.00 & -0.30 & -5.24 & 0.00 \\
\hline $\begin{array}{l}\text { Stock Price } \\
\text { average }\end{array}$ & 450 & 0.99 & 0.00 & -3.95 & -12.26 & 0.00 \\
\hline $\begin{array}{l}\text { Return } \\
\text { stock }\end{array}$ & 450 & -0.02 & 0.61 & 0.00 & 0.61 & 0.54 \\
\hline TVA & 450 & 0.25 & 0.00 & -0.00 & -2.85 & 0.01 \\
\hline
\end{tabular}

From the tables 3 and 4 show that the average spread, average stock price and TVA before and after election are different. The minimum and maximum value are tend to increase, while the value of stock return has no difference. This is evidenced by the value of sig $0.000<$ value of $\alpha$
(0.05), so it is concluded that $\mathrm{H} 1, \mathrm{H} 2$, and $\mathrm{H} 4$ are accepted. There are significant differences before and after the event of American presidential election 2016 in America (DJIA). This is not in accordance with the theory developed by Yale Hirsch (1900), mentioned that the US stock market weakened in the year of the new presidential election of America. According to this theory, after the first year the stock market will improve until the cycle begins again with the presidential election [4].

The results are in line with the Random walk theory that market price moves randomly interpreted and unpredictable when rising and falling stock prices depend on news information. The some issues regarding to US presidential election might influence share price in stock exchange market and market reaction.

\section{CONCLUSION}

Based on data analysis, to Indonesia it can be concluded that the events before and after the 2016 US presidential election is against the value of spread, the average stock price and trading volume activity, there is a decrease between before and after the 45 th presidential election of America. While for the stock return value there is no significant difference between before and after the election. The reaction of capital markets in America responded positively to the 45 -year presidential election. Spread value, stock price, stock return and trading volume activity are indicated by significant differences and tend to increase between before and after the 45 th presidential election of America, while the stock return value is no difference.

There are two main factors that influence the price shares are internal and external factors. The internal factors concerning about the condition within the company, while external factors involve the influence from outside the company such as the announcement of the government, political and economics turmoil, and issues from within the country and abroad. It can be concluded that the presidential election could be one of the factors affecting capital market reaction.

This study gives some implication on enriching the case of event study particularly in the political election. In addition, this result can be recommended for proving the fitness of Yale theory that might not suitable for political election outside America.

Future research should not only uses high low prrice spreads, average stock prices, stock returns and trading activity volumes but can also use additional exchange rate variables for foreign stock exchanges samples, add samples of other state stock exchanges to vary, increase 
the estimated period or the exact duration and number of samples and in accordance with the event study which is the model might be more optimal.

\section{REFERENCES}

[1] www.forexindonesia.org. 2016

[2] Afrianto, Dedi. Soal Pilpres AS, Dubes Singapura Asia Sumbang 2/3 Pertumbuhan Ekonomi Global. Diambil 21 November 2016 http://economy.okezone.com/read/2016/11/16/20/1543028/so al-pilpres-as-dubes-singapura-asia-sumbang-2-3pertumbuhan-ekonomi-global. 2016

[3] Husnan, Suad. Dasar-Dasar Teori Portofolio, Edisi ke dua. Jogyakarta : Percetakan AMP YKPN. 1994.

[4] Investopedia. (2017). Presidential Election Cycle (Teory). 5 February 2017, http://www.investopedia.com/terms/p/presidentialelectioncyc le.asp

[5] M. Samsul. Pasar Modal dan Manajemen Fortofolio (Edisi 2). Jakarta. Erlangga, 2015.

[6] E.F.Fama. Efficient capital Markets: A review of Theory and Empirical Work. The Journal of Finance, Vol. 25, No. 2, Papers and Proceedings of the Twenty-Eighth Annual Meeting of the American Finance Association New York, N.Y. December, 28-30, 1969 (May, 1970), pp. 383-417

[7] Tandelilin, Eduardus.Portofolio dan Investasi Teori dan Aplikasi . Edisi pertama. Yogyakarta : Kanisius. 2010.

[8] http://www.idx.co.id

[9] Yahoo Finance. My Fortofolio \& Markets. 3 January 2016, https://finance.yahoo.com/.

[10] InvestorsHub.Com. Inc. (2017). Financials Data. 4 April 2017, http://ih.advfn.com/stock-market/NYSE/mcdonalds$\mathrm{MCD} /$ financials?btn=annual_reports\&mode=company_data

[11] www.bloomberg.com

[12] Alwi, Iskandar. Pasar Modal Teori dan Aplikasi. Jakarta: Yayasan Pancur Siwah. 2008. 